\title{
WRITING THE HISTORY OF SOUTHEAST SUMATRA: A REVIEW ARTICLE
}

\author{
Heather Sutherland
}

Barbara Watson Andaya, To Live as Brothers. Southeast Sumatra in the Seventeenth and Eighteenth Centuries: Honolulu: University of Hawaii Press, 1993; xvii, 324 pp., maps, glossary, bibliography, index.

Elsbeth Locher-Scholten, Sumatraans Sultanaat en Koloniale Staat. De relatie Djambi-Batavia (1830-1907) en het Nederlandse imperialisme; Leiden: KITLV Uitgeverij, 1994; x, 368 pp., maps, appendices, glossary, bibliography, index.

In 1971 O. W. Wolters noted that "studies of Southeast Asian history must always take into account how the world was seen from a specific place." ${ }^{11}$ Reading these two books, both concerned with south Sumatra, is a powerful reminder of the complexities which underlie Wolters' apparently simple observation. For "seeing the world from a specific place" immediately raises the questions "whose place," "why that place and not another," "which world is being seen from that place," and how do you, the researcher, approach that place and that world? Such "seeing" involves a direct link between at least two locations: that of the writer, and that of the subject, as well as the relationship between the subjects and their world (or worlds). The writer's position vis-à-vis his subject is a product of choices as to theme, theory and method, and of less conscious factors such as political environment and intellectual lineage. But when we try to determine how we should place our subject in his own context, in order to understand his reactions or motives, then even more complications arise. For our access to our subject's world is indirect and usually barely documented, while that world was also differentiated. We have to ask: who was doing the seeing, which world did they see, and why?

This alarming multiplication of uncertainties is usually checked by conventional and mostly unacknowledged assumptions. These have been challenged over the last few decades. The end of colonialism and the Cold War, and the deconstruction of nationalism have undermined the reassuring polarities around which Southeast Asian history could be

${ }^{1}$ O. W. Wolters, The Fall of Srivijaya in Malay History (New York/London: Cornell University Press, 1971). 
written, while recent work on "Orientalism" and colonial ethnographies have made even the most innocent historian shrink from claiming "objectivity." Most reassessment has focused upon the relationship between researcher and subject; less upon the problems of access to the subject's world-view by the researcher. This is meat and drink to anthropologists, but most historians in the past either paid little attention to their subject's possibly autonomous world-view, or casually adopted either the essentialist assumption that natives were governed by inscrutable and inescapable cultural compulsions, or that underneath all that exotic window-dressing they were in naked pursuit of wealth and power like the rest of the world.

Barbara Watson Andaya's To Live as Brothers and Elsbeth Locher-Scholten's Sumatraans Sultanaat en koloniale staat study the same geographical area, and both are good histories. But the contrasts between them are clear. This is partly because the periods they examine-seventeenth and eighteenth as opposed to nineteenth and early twentieth centuries-encourage the use of different themes and sources, and partly because they themselves are products of dissimilar, though overlapping, institutional and intellectual traditions. Whereas both look at the same place from a primarily Dutch archive based location, their priorities are different, the former focusing on local history, the latter on imperialism. Consequently, although both consider the southeast Sumatran context, it is of primary and crucial significance in To Live as Brothers, and secondary in Sumatraans Sultanaat.

In her concluding sentence (p. 249), after referring to traditional chronicles and contemporary recollections of legendary heroes, Barbara Andaya writes "... in the end, despite the voluminous European documentation, it is in such shifting, elusive but revealing memories that the essence of southeast Sumatra's history has been retained." To Live as Brothers is written with this considerable ambition: to find the essence, the localized truth, of an Indonesian society's history, and to free it from the imposed framework of European perceptions and priorities.

This goes beyond the wish expressed in John Smail's seminal 1961 article, ${ }^{2}$ in which he argued for recognition of the internal trajectories of change in local Southeast Asian societies. Smail was concerned primarily with locally generated strategies and causation, while Andaya is more explicitly concerned with the cultural universe within which people place themselves. Ultimately, although the Netherlanders generated most of the primary sources (Dutch East India Company or VOC records) upon which her account is based, they are seen as the strangers, entering a coherent world, which they fail to understand but which they change dramatically.

In order to establish this coherence Andaya highlights several themes. She begins by locating the Dutch in their own seventeenth-century European world, where literacy is replacing orality, creating new measures of time and value. The southeast Sumatran world was still based on orality, and although various groups within this world pursued their own ambitions, they shared a common cultural context. Andaya identifies three central preoccupations of that culture. They are first, kinship, with all its creative ramifications, structuring, explaining, and legitimizing all human relationships; second, the negotiated ambivalence of upstream/downstream interaction; and third, the ambiguous role of kings, as leaders of lineages which include potential rivals, and as mediators, who are either remembered as heroes embodying Good Times, or forgotten as failures whose legitimacy so easily evaporated.

\footnotetext{
2 John R. W. Smail, "On the Possibility of an Autonomous History of Modern Southeast Asia," Journal of Southeast Asian History 2, 2 (1961): 72-102.
} 
Attempts to isolate "the essence" of a culture other than that of the writer can be like a red rag to a bull, encouraging ferocious charges of Orientalist reductionism. But such attempts are a prerequisite for the understanding which must underlie acknowledgment of the reality of that other culture. If the "essence" extracted does identify predominant characteristics, then the alien can become accessible, and the resulting recognition of a common humanity enables readers to comprehend the dynamics of the society involved. Watson Andaya has, I believe, succeeded in this; however, the Netherlanders who came to Jambi and Palembang in the 1600 s and 1700 s did not have the benefit of her insights.

Each of these three fundamental concerns of southeast Sumatran society was misunderstood by the Dutch; they saw the giving of women as sexual looseness, upstream as naturally subordinate to their familiar coast, while kings were expected to be powerful monarchs, overriding the demands of family and nobles. This juxtaposition of European and Indonesian cultures within the framework of the evolution of literacy has the great advantage that neither is reduced to being an exotic alien in a "real" world: both are rooted in a common pattern of cultural change. Neither is superior or inferior, both are all too human. Add to this the distillation of dominant themes in southeast Sumatran culture, to present it as comprehensible and patterned, and the linking of these themes to specific events in a chronological narrative, then the thought which has gone into structuring this book becomes clear. But Watson Andaya was not content with this: To Live as Brothers is, as its title also suggests, a comparative study, tracing the contrasting experiences of Jambi and its southern neighbor Palembang through their involvement in the pepper trade, their contacts with the VOC, and their attempts to negotiate the turbulent waters of regional politics.

The narrative sections of the book, unraveling a complex and little known history, are lucid and thoughtful, careful not to push interpretation beyond its sustainable foundations. It is a measure of Watson Andaya's achievement that, for this reviewer at least, these sections-the raison d'etre for lesser books-are subsidiary to the descriptions of context and explanation of meaning. Her accounts of the role of women, of the Chinese, or of Minangkabau gold mining are both learned and fascinating.

Jambi and Palembang were brothers, neighbors, and rivals. The comparison between them underlines how new economic interests, notably in pepper, gold, and tin, generated political instability and realignments: between members of the royal clans, between kings and nobles, between upstream and downstream, between Minangkabau immigrants and established interior groups, between local courts and other political players, especially the VOC and Mataram.

The end result was that Jambi, after the seventeenth-century pepper boom had ensured its fraternal superiority for two generations, went into decline in the late 1600s. Palembang, on the other hand, which was spared Minangkabau incursions, and could buttress its pepper income with Bangka tin, was able to use its wealth to expand in power and prestige through the eighteenth century. During this period the Dutch were wary manipulators of local politics rather than heavy-handed colonials. Nonetheless, their influence and suspicion of Indonesian alliances did much to undermine the cultural mechanisms that had moderated local tensions, particularly between upstream and downstream.

In the early 1800 s the Dutch changed gear, entering the imperial century. This is the theme of Elsbeth Locher Scholten's study, which is, as she intended, a very different sort of book. The question that opens her book makes that clear: "Was there a Dutch imperialism?" (p.1). Her aim is to use the relationship between Batavia (not The Hague) and Jambi between 1830 and 1907 to examine the nature of Dutch colonial expansion. Whereas Barbara 
Watson Andaya begins by considering how one could get a grip on the history of southeast Sumatra, Locher-Scholten's introduction to "themes and theories" focuses on the imperialism debate in general and in the Netherlands in particular. ${ }^{3}$

Jambi offers a particularly interesting case study for examining imperial attitudes, because of Sultan Ratu Taha Safiuddin's protracted resistance to colonial control. Three years after his accession in 1855, he refused to sign a new contract, was deposed, and fled upstream to Muara Tebo where he maintained an alternative capital to that of the Dutchsponsored rulers downstream. His resistance lasted nearly fifty years, ending only when he was killed in 1904, after challenging generations of policy makers and soldiers to overcome this anomaly in their increasingly orderly domain. But although Taha was a particularly stubborn problem, Locher's description of preceding and subsequent decades in Jambi, and her comparative examination of other colonial enterprises, ensures that he remains firmly in context.

Locher's approach to imperial history recognizes the importance of local realities, of the diverging interpretations of Netherlanders and Jambi people. She considers precolonial (pp. 18-21), Malay, and Jambi (pp. 36-39) state structures, while noting (p. 43) that, although European opinions of those states were overwhelmingly negative, their own Western political institutions were not always so very different. Like Watson Andaya (pp. 145-48), Locher (pp. 71-75) also focuses on different interpretations of contracts, while her Chapter VII presents an entertaining account of political maneuvers in the late nineteenth century seen as "ritual dances."

Sumatraans sultanaat en koloniale staat traces several narrative and analytic lines through the period of colonial expansion and, in an epilogue of some thirty pages, to the end of Dutch political power in 1949. In this epilogue the two main themes running through most imperial history continue to predominate: economic interest (oil, rubber), and political conflict, particularly the revolt of 1916 and the revolution of 1945-1949. In the earlier chapters the author's narrative focuses upon the interaction between Batavia (the Asian colonial capital) and its representatives, and between European officials and Jambi leaders. Due attention is given to the context within which these actors operated: Batavia's "sub-imperialism" had its problems with The Hague, high policy met problems on the ground, and officials found themselves playing roles in Jambi power-plays which were seldom fully understood.

Locher-Scholten's conclusion is that the Dutch push to imperial expansion was, as could be expected, driven by a complex of motives. It was not so much fear of foreign competition, or economic interest, let alone moral imperatives, that underlay Dutch imperialism, although each played its part. More important was the need to build a strong state (p. 292), which could guarantee security, confer prestige, and generate and protect the infrastructure and investment necessary for the linking of local economies and world markets. States like Jambi, which had been erratic but essential allies in earlier centuries, were simply inadequate to the demands of the new era.

For the Dutch or Chinese seeking the products of Jambi and Palembang during the seventeenth and eighteenth centuries, there was no alternative to working with existing political systems of exploitation. Chinese pepper traders recognized the necessity of cultural

\footnotetext{
${ }^{3}$ For an account of the main points non-Dutch readers can turn to her "Dutch Expansion in the Indonesian Archipelago around 1900 and the Imperialism Debate," Journal of Southeast Asian Studies 25,1 (March 1994): 91111.
} 
incorporation, and allied themselves with Jambi or Palembang families, so gaining both wealth and influence. When they threatened to grow too independent or powerful, as in late eighteenth-century Bangka (Watson Andaya, pp. 218-19), the Sultan was able to restrict their activities. The Dutch remained outside, or, as they thought, above, local political systems, and were continually frustrated by their inability to use them effectively as instruments. But by the 1820 s weakened internal cohesion and Anglo-Dutch maneuverings led to aggressive intervention by Netherlands Indies forces. The balance of power shifted, and this seems also to lead to more external historical perspectives.

The early modern period in Southeast Asia can be approached from several directions, and so too can the nineteenth or twentieth centuries, should we choose to do so. Southeast Sumatra during the seventeenth and eighteenth centuries can be looked at in terms of European commerce, of Indian ocean trade, of Chinese networks, of Dutch expansion, or it can be placed in the locally grounded perspective of Watson Andaya. Similarly, an alternative approach to the imperial analysis of Locher-Scholten could build on the introductory sections of To Live as Brothers, tracing the ongoing ascension of literacy over orality into contemporary Indonesia. We could follow the three core themes from this book through the modern history of the region. How have the conceptualizations of human relationships, the linkage between regions, ideas of political authority, and the mental maps locating identity in a changing world developed under the impact of nation state and world market since the Dutch began their forcible advance? Has the advance of "modernity" overcome the mutual incomprehension of oral Indonesian culture and literate European, fusing them into a new national culture, borne by Inpres schools and TVRI? Or has the frontier become internal, within Indonesia, dividing social classes or regional cultures?

Such questions do not seem to fall within the domain of the historian, but we should at least claim the nineteenth and early twentieth centuries. ${ }^{4}$ Interestingly, although there are pitifully few practitioners, early modern Southeast Asian history has produced some important books in the last few years, which break with simplistic East/West dichotomies, and ask Big Questions. ${ }^{5}$ Books like To Live as Brothers, or Merle Ricklefs' latest work, ${ }^{6}$ combine a commitment to investigating central questions of structural change with the virtues of the detailed monograph exploiting difficult source material to break new ground. It could be expected that it would be much easier for historians of the colonial period to $d n$ the same, integrating cultural, social, theoretical, and comparative dimensions. But the very factor which should stimulate this, the relative wealth of documentation, seems to inhibit it, as if the miles of archives transfix us, preventing us from creative use of press, visual, or oral material.

Both the books reviewed here deserve praise, for they have achieved their aims. LocherScholten's book, written in Dutch, with each chapter divided into labeled thematic subsections, is an excellent teaching tool for work on the Netherlands imperial project, and a solid, enjoyable monograph on Jambi history. Her extensive archive work, in both Holland and Indonesia, her explicit reference to secondary theoretical works, and her useful lists means

\footnotetext{
4 See, for example, Takahashi Shiraishi, An Age in Motion (Ithaca: Cornell University Press, 1990).

5 A stimulating recent contribution is A. J. S. Reid's two-volume Southeast Asia in the Age of Commerce (New Haven and London: Yale University Press, 1988 and 1993). Finding Big Answers, however, is more difficult. See for example Remco Raben, "The Broad Weft and Fragile Warp: Conference on the Eighteenth Century as a Category in Asian History," Itinerario 18, 1 (1994): 10-18, a report of a conference at the Netherlands Institute of Advanced Studies, Wassenaar, 1993, June 2-5.

6 M. C. Ricklefs, War. Culture and Economy in Java 1677-1726. (Sydney, 1993). See also Leonard Y. Andaya, The World of Maluku: Eastern Indonesia in the Early Modern Period (Honolulu: University of Hawaii Press, 1993).
} 
her analysis is transparent and accessible. (The only quibbles are stylistic: the irritating citation of authors' names in the text and the inadequate index, both blots on the otherwise excellent KITLV monograph series). But all in all, Sumatraans sultanaat en koloniale staat deserves the warm reception it has received in the Dutch media.

To Live as Brothers is a more ambitious work, in which bold decisions on themes and structure impose order on the tangle of events, of peoples, and on the problems of sources and interpretation. Some might find the solutions too bold, the use of folk tales and nineteenth-century material too risky. But historians sometimes should stand up and be counted: if they have paid their dues in exhaustive archive work, if they feel that no one else is likely to reach the same level of familiarity with all the available material, then the courage to attempt a full interpretative account can only be admired. And in this case, when the documentation is clear, and the sense of place and time convincing, the book does indeed deserve our admiration.

Taken together, these two books can be seen as covering four hundred years of southeast Sumatra's past. But they offer much more than that; both are signs of the increasing maturity of the history writing of Indonesia. In Barbara Andaya's work we have an excellent example of the regional historiography which developed, mainly in the United States and Australia, after the early 1960s. It is also regional history at its best, as it contributes to our understanding of comparative thematic and structural change. Elsbeth Locher's book is also a source of pleasure, underlying as it does how Dutch colonial and imperial history is increasingly connecting not only to international debates, but also to a positive recognition of the Indonesian contribution to the common past. 